\title{
Persamaan Struktur Loyalty Modelling Pengguna Public Transport Railway MRT- SBK Greaters Kuala Lumpur Malaysia
}

\author{
Amsori M Das \\ Fakultas Teknik Universitas Batanghari Jambi \\ Correspondence email: amsori.m.das@unbari.ac.id
}

\begin{abstract}
In the context of transportation, the passenger loyalty is a measurement of the level of passenger's willingness to use a similar public transport. The goal of this study is to examines and identifies factors that influencing passenger loyalty. Three factors such as satisfaction, service value, services quality was predicted as an influential factor towards passengers' loyalty. The Mass Rapid Transit (MRT) for Sungai Buloh to Kajang (SBK) line in Kuala Lumpur conurbation was used as a case study and 555 respondents have contributed to this study. Structural equation modelling (SEM) was used to investigate the relationship between service quality, service value, passenger satisfaction and passenger loyalty. Satisfaction has the most significant influence on passenger loyalty. Service value has direct and positive effects on passenger loyalty. This study also found the service quality has significant indirect effect on the passenger loyalty via service value and passenger satisfaction.The structural model for investigating the loyalty of MRT-SBK users to this service has been analysed and tested using the service quality, satisfaction and quality value showed $75 \%$ positive change for all variables. These models recorded average errors and absolute index evaluation in accepted criteria of $\leq 0.09$ and $\geq 0.94$ respectively. The study reveals that MRT-SBK passengers' loyalty is significantly influenced by service attributes, such as vehicle safety, convenience, punctuality, comfort, cleanliness of the facility provided. This study helps MRT service provider to optimize resource to enhance user's satisfaction and therefore, increase the passenger loyalty
\end{abstract}

Keywords: Service Quality; Satisfaction; Service Value; Loyalty; Structure Equation Modelling MRT-SBK

\section{PENDAHULUAN}

Meningkatnya problem transportasi perkotaan terutama kemacetan lalulintas di jalan raya dan pencemaran lingkungan merupakan isu global serta menjadi masalah vital diseluruh kota besar dunia yang berdampak mempengaruhi, kehidupan sosial, ekonomi dan kurang ramahnya lingkungan (environmental friendly). Menyebabkan pemerintah setempat dan perancang kota saat ini mengambil perhatian serius untuk mencari solusinya. Diberbagai kota-kota besar dunia (Essa et al. 2017 \& Ladin at al. 2014). demikian juga dialami Kuala Lumpur dan Lembah Klang terutama pada jam sibuk peak hour (SPAD. 2010) mengalami kemacetan lalulintas jalan raya yang serius. Pengembangan sistem publik transport berbasis rel (railway base) merupakan salah satu alternatif atau upaya untuk menjawab atau mengurangi fenomena tersebut. menurut (Mageean \& Nelson. 2003), layanan transportasi umum adalah bagian dari infrastruktur dasar dan esensial dalam pembangunan suatu negara. Publik Transport yang baik dan komprehensif sangat berperan vital untuk menarik investor dan wisatawan asing. Selain itu, efisiensi dan efektifitas sistem transportasi umum menentukan (image) modernitas pembangunan suatu bangsa.

Di Kuala Lumpur dan Lembah Klang, dalam periode 1960 hingga 1990, layanan bus mini adalah moda transportasi umum yang paling populer. Ternyata, tidak seperti kota-kota negara Asia lainnya, penggunaan publik transportasi masih rendah karena hanya $16 \%$ dari jumlah populasi (Bernama. 2009). Pada akhir tahun
2012, kerajaan menargetkan 600.000 atau 25\% dari populasi Kuala Lumpur dan Lembah Klang untuk menggunakan transportasi umum di Malaysia di bawah inisiatif Bidang Keberhasilan Utama Negara (NKRA).

Akhirnya, melalui Rancangan Malaysia ke-10. Kerajaan bertujuan untuk meningkatkan penggunaan publik transportasi dari $12 \%$ pada tahun 2009 menjadi 30\% pada tahun 2015 (Bernama. 2010). Saat ini, tranportasi umum di Kuala Lumpur dan Lembah Klang, berkembang dari layanan bus umum ke kereta api seperti: KTM Comuter, Light Rail Transit (LRT), monorel, ERL dan MRT. Sistem transportasi umum berbasis rel yang tersedia terdiri dari dua jalur Light Rail Transit, jalur monorel, dua sistem kereta komuter yang terdiri dari empat jalur, dan jalur kereta api bandara (Airport). Selain itu, Mass Rapid Transit untuk jalur Sungai Buloh ke Kajang (MRT -SBK) pada tahun 2017 telah diperkenalkan dan dioperasionalkan sebagai pengembangan dari publik transport berbasis rel.

Masalah transportasi berbasis rel di Kuala Lumpur dan Lembah Klang adalah integrasi dan koordinasi yang belum maksimal atau masih lemah dalam memastikan ketepatan masa, kenyamanan dan aksesibilitas untuk semua penumpang (Yahia at al. 2017).

Sebagai elemen utama dan vital untuk publik transport MRT-SBK dapat bertahan di pasar transportasi umum adalah bagaimana mempertahankan keunggulan kompetitif dan mengembangkan strategi pelayanan dan pemasaran yang efektif. Loyalitas pengguna adalah salah satu indikator yang paling sering digunakan untuk 
mengukur keberhasilan strategi pemasaran (Flavian at al. 2001). Pentingnya loyalitas pengguna mengarah pada retensi pelanggan, pembelian atau penggunaan kembali, hubungan pelanggan jangka panjang dan profitabilitas. Pelanggan yang setia atau loyal kemungkinan akan terus menggunakan layanan dan merekomendasikan layanan ini kepada rekan atau keluarga mereka. Dengan demikian, mengembangkan dan mempertahankan loyalitas pengguna adalah kunci untuk kelangsungan hidup dan pertumbuhan infrastruktur publik transportasi dan perusahaan jasanya. Loyalitas pengguna telah mendapat perhatian besar dari akademisi dan praktisi, terutama dibidang service dan pemasaran/ marketting. Namun masih sedikit yang ditemukan di industri transportasi, kecuali untuk industri transportasi penerbangan atau udara.

Dengan demikian, penelitian ini dilakukan untuk menyelidiki faktor penting yang mempengaruhi loyalitas pengguna MRT-SBK. Penelitian ini menggunakan analisis faktor untuk mengekstraksi konstruk kualitas layanan dari sejumlah besar indikator kualitas layanan. Hubungan sebab akibat dari loyalitas pengguna dan konstruk nilai layanan serta konstruk kepuasan, kemudian diidentifikasi dengan pemodelan persamaan struktural. Hasil estimasi model persamaan struktural dapat memberikan implikasi penting bagi pihak manajemen publik transport berasas rel mass rapid transit (MRT-SBK).

\section{METODE \\ Data dan Pengumpulan Sampel}

Survei desain cross sectional digunakan untuk mengumpulkan data demografi pengguna MRT-SBK, karakteristik perjalanan dan data loyalitas pengguna. Jalur Sungai Buloh Kajang (Panjang lintasan $51 \mathrm{~km}$ dengan 31 stasiun dan jalur bawah tanah 9,5 km) yang terletak di koridor barat dan timur Kuala Lumpur dipilih sebagai lokasi studi seperti ditunjukkan pada Gambar. 1. Data efektif dari total 555 penumpang dikumpulkan pada bulan Februari sampai dengan Agustus 2018. Kualitas layanan, loyalitas penumpang, dan konstruk yang relevan tidak dapat diukur secara langsung. Beberapa indikator biasanya digunakan untuk merepresentasikan konstruk. Instrumen kualitas layanan standar untuk MRT-SBK tidak tersedia dalam literatur. Dalam penelitian empirik ini, kualitas layanan dikembangkan berdasarkan studi sebelumnya dan skala SERVQUAL, ukuran kualitas layanan yang paling banyak digunakan (Parasuraman, 1885). SERVQUAL adalah instrumen untuk mengukur kualitas layanan seperti yang dirasakan oleh pengguna.

Instrumen pertama mempunyai 28 -item kemudian setelah uji pengukuran CFA menghasilkan 17 item yang digunakan dalam penelitian ini. Faktor-faktor loading tersebut dinilai menggunakan skala Likert 5 poin mulai dari "sangat tidak puas" sehingga "sangat puas."

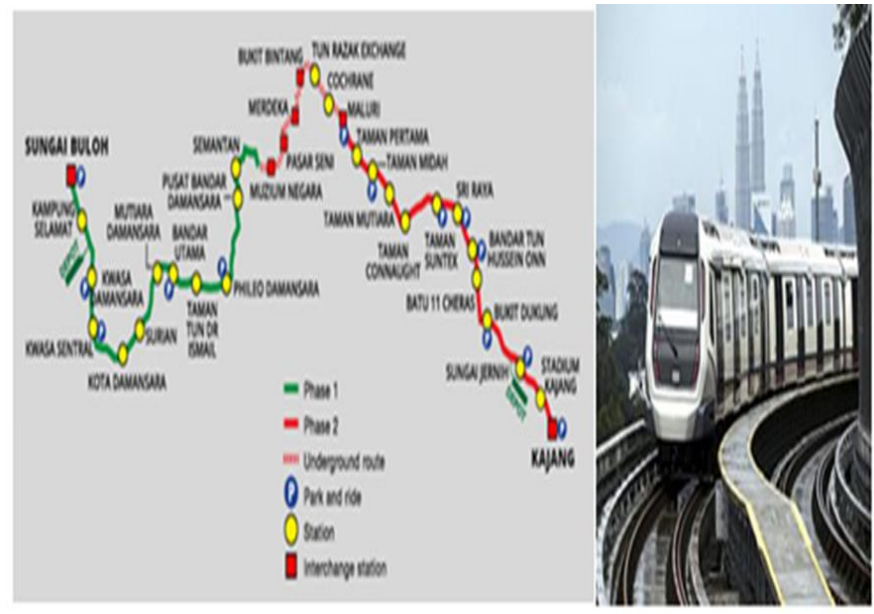

Gambar 1. Mass Rapid Transit Track dan Line Sungai BulohKajang (MRT-SBK)

\section{Pendekatan Analisis}

Berdasarkan kajian literatur, dalam penelitian ini mengusulkan konsep model seperti yang ditunjukkan pada Gambar. 2. Penelitian Loyalty Model MRT-SBK ini terdiri dari enam hipotesis sebagai berikut:

H1: Kualitas layanan yang dirasakan memiliki hubungan positif dan signifikan pada nilai layanan.

H2: Kualitas layanan memiliki hubungan positif dan signifikan kepada kepuasan.

H3: Kualitas layanan yang dirasakan memiliki hubungan positif signifikan kepada loyalitas pengguna.

H4: Nilai layanan yang dirasakan memiliki hubungan positif dan signifikan kepada kepuasan.

H5: Nilai layanan yang dirasakan memiliki hubungan positif dan signifikan kepada loyalitas pengguna.

H6: Kepuasan yang dirasakan memiliki hubungan positif dan signifikan kepada loyalitas pengguna.

Penelitian ini mengembangkan model untuk menguji enam hipotesis ini, seperti yang ditunjukkan pada gambar dua. Menggunakan pendekatan statistik teknik multivariat yang menggabungkan regresi berganda dan analisis faktor untuk memperkirakan serangkaian korelasi ketergantungan yang saling terkait secara bersamaan. Structural Equation Modeling (SEM) meliputi model pengukuran dan model struktural. Model pengukuran, yang disebut analisis faktor konfirmatori, menggambarkan seberapa baik indikator yang diamati dalam mengukur variabel (laten) yang tidak teramati. Model struktural, yang disebut analisis jalur, mengidentifikasi korelasi sebab akibat di antara variabel.

Ketika semua item atau faktor beban kualitas layanan dimasukkan dalam model pengukuran, model tersebut belum sesuai dan menghasilkan indikator yang 
baik. Untuk mengatasi masalah itu, analisis faktor eksplorasi digunakan untuk mengurangi jumlah item kualitas layanan menjadi beberapa faktor beban dan untuk menentukan item indikator tersebut.

Analisis komponen utama dengan rotasi miring digunakan sebagai metode ekstraksi pada sampel. Jumlah faktor ditentukan oleh kriteria nilai eigen yang lebih besar dari atau sama dengan 1,0. Item dipertahankan dalam hasil akhir jika loading faktornya lebih besar dari 0,5. Koefisien alpha dihitung untuk menilai keandalan faktor-faktor tersebut.

Analisis faktor eksplorasi tidak memungkinkan penilaian statistik untuk model yang ditentukan sebelumnya dan pengujian eksplisit untuk validitas konstruk dan non-dimensi (Anderson \& Gerbing 1988).

Sebaliknya, analisis faktor konfirmatori CFA memungkinkan seseorang untuk secara eksplisit menyatakan satu atau lebih model prioritas dan secara sistematis membandingkan kemampuan model yang kompeten agar sesuai dengan data yang diamati (Bollen. 1989).

Pengujian validitas konstruk mencakup validitas konvergen dan validitas diskriminan. Validitas konvergen mengacu pada sejauh mana setiap pengukuran berkorelasi dengan langkah-langkah lain dari konstruk laten yang sama. Validitas konvergen dapat dinilai melalui nilai-t. ( $t$-value). Jika nilai-t lebih besar dari 2,58, item signifikan pada level 0,01.

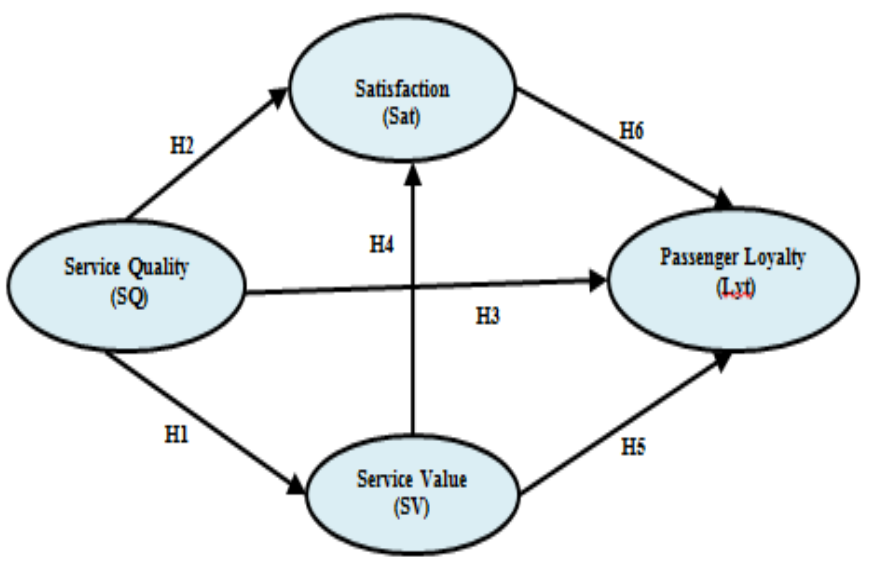

Gambar 2. Model struktural diusulkan untuk menguji loyalitas pengguna MRT-SBK

Sebaliknya, Discriminant validity atau validitas diskriminatif mengacu pada sejauh mana ukuran suatu tindakan tidak berkorelasi dengan ukuran-ukuran konstruksi lainnya. Validitas diskriminan dapat dinilai berdasarkan interval kepercayaan korelasi antara dua konstruk. Jika tidak ada korelasi termasuk satu, validitas diskriminan tercapai. Indeks modifikasi dan residu standar dapat digunakan untuk menilai non-dimensi. Berbagai pengukuran good-of-fit digunakan untuk mengevaluasi ke sohehan dan kesesuaian dengan data dari model yang dihipotesiskan dalam penelitian ini.

\section{HASIL DAN PEMBAHASAN \\ Karakteristik dan Demografi}

Sebanyak 555 responden yang valid dikumpulkan dalam penelitian ini. Dari total responden, sekitar 64\% (355 responden) adalah laki-laki dan 36\% (200 responden) adalah perempuan. Selain itu, usia $11 \%$ dari responden berusia di bawah 20 tahun; $62 \%$ antara 21 hingga 30 tahun; 17,3\% antara 31 hingga 40 tahun; 7,4\% antara 41 hingga 50 tahun; dan 2,3\% di atas 50 tahun. Peserta juga diminta untuk menyebutkan lokasi tempat tinggal mereka. Dari responden, $11,7 \%$ berasal dari Kuala Lumpur, sedangkan $88,3 \%$ sisanya berasal dari Selangor atau luar negeri lain. Mengenai pekerjaan peserta, 29,7\% adalah pelajar, 50,8\% adalah karyawan penuh waktu, $18,6 \%$ adalah karyawan paruh waktu, $0,7 \%$ terlibat dalam berbagai jenis pekerjaan, dan $0,2 \%$ tidak bekerja. Sehubungan dengan profil pendapatan para responden, $4,7 \%$ berpenghasilan kurang dari RM1000, 14,2\% berpenghasilan antara RM1000 RM2000, 65,8\% berpendapatan antara RM2000 RM3000, 9,5\% berpenghasilan antara RM3000RM5000, 5,8\% berpenghasilan RM5000 atau lebih.

\section{Model Pengukuran}

Analisis Faktor Konfirmatori (CFA) digunakan untuk memperkirakan validitas konvergen dan diskriminan dengan menggunakan perangkat lunak atau Software AMOS V.22. Indeks good-of-fit keseluruhan dari model pengukuran CFA menunjukkan kesesuaian dan memuaskan dari model pengukuran dengan Chisquare derajat kebebasan $(\chi 2 / \mathrm{df}=2,71$; RMSEA $=$ 0,$056 ; \mathrm{NFI}=0,883 ; \mathrm{CFI}=0,923 ; \mathrm{GFI}=0,891 ; \mathrm{AGFI}=$ 0,871 ; TLI $=0,915$.) Validitas konvergen memastikan bahwa ukuran item atau indikator memiliki faktor beban yang menunjukkan konvergensi setiap indikator pada satu titik. Literatur telah menetapkan tiga kriteria untuk mengukur konvergen pada satu titik.

Berdasarkan standart atau literatur telah menetapkan tiga kriteria untuk mengukur validitas konvergen (Hair at al. 1998).

Karena RMR dan RMSEA masing-masing kurang dari 0,10 hinga 0,08 , model dapat dinyatakan signifikan dan dapat diterima secara empiris (Fornell at al, 1996)

1. Faktor beban atau indikator untuk setiap item harus dianggap signifikan dengan mempunyai nilai melebihi 0,5 .

2. Reliability atau keandalan untuk setiap konstruk harus mempunyai nilai lebih daripada 0,70 .

3. The average variance extracted (AVE) atau Varians rata-rata yang diekstraksi untuk setiap konstruk harus mempunyai nilai lebih dari 0,50 .

Tabel I dan II menunjukkan bahwa semua nilai indikator CFA melebihi 0,5 dan signifikan pada $\mathrm{p}=$ 0,01 , kecuali untuk beberapa item dengan kualitas layanan yang dirasakan, yang memiliki faktor beban kurang dari 0,5; item ini digugurkan dari analisis lebih 
Amsori M Das, Persamaan Struktur Loyalty Modelling Pengguna Public Transport Railway Base MRT-SBK Greaters Kuala Lumpur Malaysia

lanjut. Analisis komposit reliability (CR) menunjukkan bahwa semua konstruk memiliki nilai di atas nilai ambang batas yang disarankan 0,5 (Hair. 2009). Keandalan konstruksi berkisar antara 0,814 dan 0,903, di mana semua nilai melebihi nilai ambang batas 0,7. Selain itu, AVE berkisar antara 0,506 dan 0,757, yang juga di atas nilai 0,5 sehingga model tersebut signifikan dan dapat diterima.

Akar kuadrat dari AVE lebih besar dari semua korelasi silang lainnya. Oleh karena itu, model pengukuran ini menunjukkan bahwa validitas konvergen dan diskriminan memiliki tingkat keandalan yang tinggi, seperti yang disarankan oleh penelitian sebelumnya. Selain itu, alpha Cronbach berkisar antara 0,725 dan 0,900 , dimana semua nilai melebihi nilai minimum 0,7 seperti yang direkomendasikan oleh (Byrne 2010).

Tabel I. Standar Loding faktor di dalam keseluruhan model

\begin{tabular}{|c|c|c|c|}
\hline \multicolumn{4}{|c|}{ CFA } \\
\hline $\begin{array}{l}\text { Konstruk/ } \\
\text { Items }\end{array}$ & $\begin{array}{l}\text { Faktor } \\
\text { beban }\end{array}$ & $\begin{array}{c}\text { Item } \\
\text { Digugurkan }\end{array}$ & $\begin{array}{c}\text { Factor } \\
\text { beban kedua }\end{array}$ \\
\hline \multicolumn{4}{|c|}{ Service Quality (SQ) } \\
\hline SQ1 & 0.600 & & 0.766 \\
\hline SQ2 & 0.512 & Dropped & \\
\hline SQ3 & 0.393 & Dropped & \\
\hline SQ4 & 0.599 & Dropped & \\
\hline SQ5 & 0.607 & Dropped & \\
\hline SQ6 & 0.460 & Dropped & \\
\hline SQ7 & 0.520 & Dropped & \\
\hline SQ8 & 0.557 & Dropped & \\
\hline SQ9 & 0.669 & Dropped & \\
\hline SQ10 & 0.695 & & 0.725 \\
\hline SQ11 & 0.640 & & 0.695 \\
\hline SQ12 & 0.564 & Dropped & \\
\hline SQ13 & 0.641 & & 0.703 \\
\hline SQ14 & 0.379 & Dropped & \\
\hline SQ15 & 0.491 & Dropped & \\
\hline \multicolumn{4}{|l|}{ Service Value (SV) } \\
\hline SV1 & 0.749 & & 0.748 \\
\hline SV2 & 0.711 & & 0.712 \\
\hline SV3 & 0.786 & & 0.789 \\
\hline SV4 & 0.681 & & 0.681 \\
\hline SV5 & 0.619 & & 0.616 \\
\hline \multicolumn{4}{|l|}{ Satisfaction (SAT) } \\
\hline SAT1 & 0.924 & & 0.924 \\
\hline SAT2 & 0.908 & & 0.909 \\
\hline SAT3 & 0.769 & & 0.768 \\
\hline \multicolumn{4}{|l|}{$\begin{array}{l}\text { Passenger Loyalty } \\
\text { (LYT) }\end{array}$} \\
\hline LYT1 & 0.826 & & 0.827 \\
\hline LYT2 & 0.756 & & 0.755 \\
\hline LYT3 & 0.843 & & 0.842 \\
\hline LYT4 & 0.839 & & 0.839 \\
\hline LYT5 & 0.747 & & 0.747 \\
\hline
\end{tabular}

Tabel 2. Hasil Cronbach alpha dan validitas konvergensi untuk model CFA

\begin{tabular}{|c|c|c|c|c|}
\hline & & & & \\
\hline & Internal & & Average & \\
\hline & & Final & & Composite \\
\hline Konstruk/ & Reliability & & Variance & \\
\hline & & Faktor & & Reliability \\
\hline Items & Cronbach & & Extracted & \\
\hline & Alpha & beban & $(\mathbf{A V E})^{\mathbf{a}}$ & (CR) \\
\hline Service Quality & & & & \\
\hline$(\mathrm{SQ})$ & 0.725 & & 0.522 & 0.814 \\
\hline SQ1 & & 0.766 & & \\
\hline SQ10 & & 0.725 & & \\
\hline SQ11 & & 0.695 & & \\
\hline SQ13 & & 0.703 & & \\
\hline Service Value & & & & \\
\hline & 0.835 & & 0.506 & 0.836 \\
\hline$(\mathrm{SV})$ & & & & \\
\hline SV1 & & 0.748 & & \\
\hline SV2 & & 0.712 & & \\
\hline SV3 & & 0.789 & & \\
\hline SV4 & & 0.681 & & \\
\hline SV5 & & 0.616 & & \\
\hline Satisfaction & & & & \\
\hline & 0.896 & & 0.757 & 0.903 \\
\hline (SAT) & & & & \\
\hline SAT1 & & 0.924 & & \\
\hline SAT2 & & 0.909 & & \\
\hline SAT3 & & 0.768 & & \\
\hline Passenger & & & & \\
\hline Loyalty & & & & \\
\hline (LYT) & 0.900 & & 0.645 & 0.901 \\
\hline LYT1 & & 0.827 & & \\
\hline LYT2 & & 0.755 & & \\
\hline LYT3 & & 0.842 & & \\
\hline LYT4 & & 0.839 & & \\
\hline LYT5 & & 0747 & & \\
\hline
\end{tabular}

Note: $\mathrm{GFI}=0.941 ;$ AGFI $=0.920 ; \mathrm{CFI}=0.968 ; \mathrm{NNFI}=$ $0.937 ; \mathrm{NFI}=0.922 ; \mathrm{RMR}=0.020 ; \mathrm{RMSEA}=$ $0.053 ; \chi 2 / \mathrm{df}=2.998$

\section{Model Struktural dan Pengujian Hipotesis}

Tahapan proses selanjutnya setelah memverifikasi model pengukuran adalah estimasi koefisien struktural diantara model keseluruhan untuk memberikan dasar pengujian daripada hipotesis yang diajukan. Model Lengkap atau Model struktur dalam penelitian ini seperti yang ditunjukan pada Gambar. 3 .

Dari estimasi didapatkan hasil nilai tes GFI melebihi persyaratan minimum $(\mathrm{GFI}=0,941 ; \mathrm{AGFI}=$ 0,$920 ; \mathrm{CFI}=0,968 ; \mathrm{NNFI}=0,937 ; \mathrm{NFI}=0,922 ; \mathrm{RMR}=$ $0,020 ;$ RMSEA $=0,053 ; \chi 2 / \mathrm{df}=2.998)$, yang mencerminkan nilai positif dan signifikan yang memadai dari semua item yang diuji untuk memprediksi Model loyaliti pengguna publik transport berasas rel MRTSBK. 

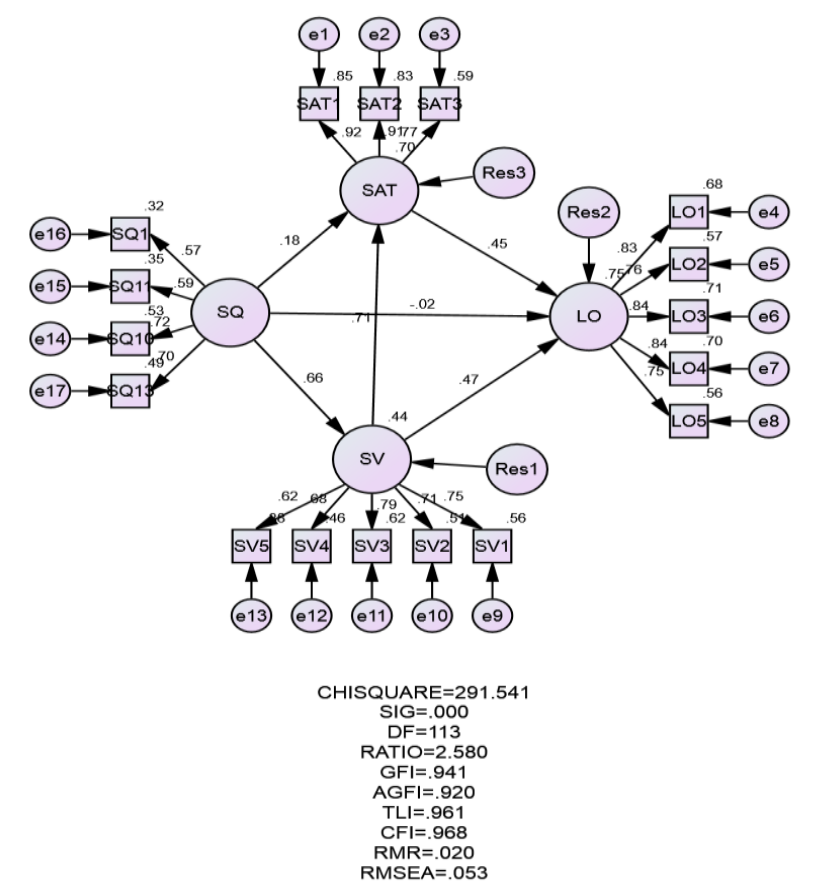

Gambar 3. Estimasi persamaan struktural model loyalty

Dari hasil estimasi persamaan model struktur menggunakan Sofware AMOS. V22 $(* \mathrm{p}<0.05, * * \mathrm{p}<0.01, * * * \mathrm{p}<0.001) \quad$ didapatkan gambar model struktur loyalitas pengguna MRT-SBK seperti dalam gambar 4

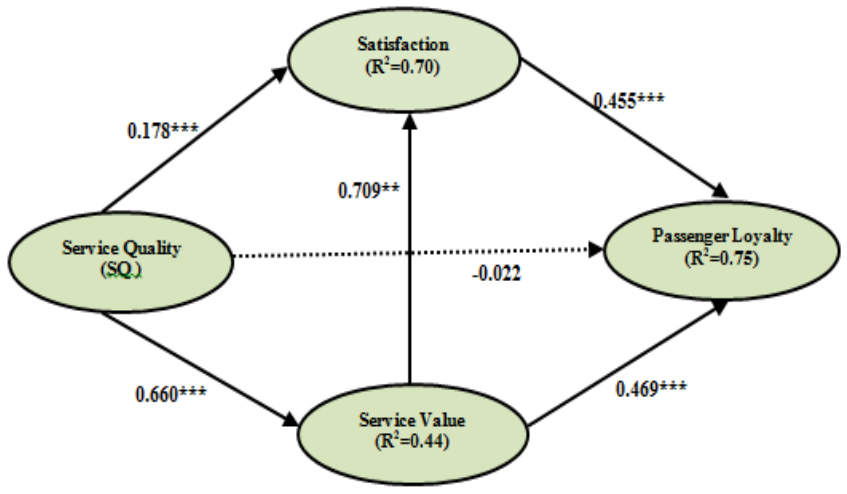

Gambar 4. Hasil model struktur model loyalty pengguna MRT-SBK

Estimasi parameter yang diperoleh melalui SEM. Berdasarkan nilai uji-t, semua hipotesis positip dan signifikan kecuali hipotesis 3 (H3). Dengan demikian, hipotesis yang diajukan dalam penelitian ini mengukur bahwa kualitas layanan memiliki efek positif dan berkorelasi langsung ke nilai layanan (H1) dan kepuasan pengguna (H2). Selain itu, nilai layanan juga secara positif dan signifikan mempengaruhi kepuasan pengguna (H4). Hasil penelitian ini mengungkapkan bahwa nilai layanan (H5) dan kepuasan pengguna (H6) memiliki hubungan positif dan langsung serta signifikan dengan loyalitas terhadap layanan MRT-SBK. Ringkasan model hipotesis pada penelitian ini ditunjukan dalam Tabel 3.
Tabel 3. Pengujian Hipotesis

\begin{tabular}{|c|c|c|c|}
\hline Path relationships & $\begin{array}{l}\text { Structural } \\
\text { coefficients }\end{array}$ & t-value & $\begin{array}{c}\text { Test } \\
\text { result }\end{array}$ \\
\hline $\begin{array}{l}\text { H1: Service quality on } \\
\text { service value }\end{array}$ & $0.660 * * *$ & 11.03 & Support \\
\hline $\begin{array}{l}\mathrm{H} 2 \text { : Service quality on } \\
\text { satisfaction }\end{array}$ & $0.178 * * *$ & 3.38 & Support \\
\hline $\begin{array}{l}\text { H3: Service quality on } \\
\text { passenger loyalty }\end{array}$ & -0.022 & -0.45 & Reject \\
\hline $\begin{array}{l}\text { H4: Service value on } \\
\text { satisfaction }\end{array}$ & $0.709 * * *$ & 12.34 & Support \\
\hline $\begin{array}{l}\text { H5: Service value on } \\
\text { passenger loyalty }\end{array}$ & $0.469 * * *$ & 6.43 & Support \\
\hline $\begin{array}{l}\text { H6: Satisfaction on } \\
\text { passenger loyalty }\end{array}$ & $0.455 * * *$ & 6.92 & Support \\
\hline
\end{tabular}

\section{SIMPULAN}

Penelitian ini bertujuan untuk menyelidiki hubungan antara faktor-faktor yang mempengaruhi loyalitas pengguna terhadap publik transport berbasis rel MRT-SBK sebagai alternatif perjalanan harian masyarakat atau pengguna. Objektif yang focus dan penting dalam penelitian ini adalah mengamati dan estimasi dengan akurat korelasi hubungan antara konstruk yang digunakan seperti: kualitas layanan, kepuasan pengguna dan nilai layanan terhadap loyalitas pengguna MRT-SBK. Oleh karena itu, penelitian ini untuk berkontribusi membantu manajemen MRT. Corp Prasarana Malaysia Berhad untuk mengoptimalkan sumber daya supaya dapat meningkatkan loyalitas pengguna dan jumlah penumpang serta untuk menjadi salah satu referensi akademis tentang kajian publik transportasi.

Penelitian ini juga menemukan bahwa, model yang diusulkan menyumbang $70 \%$ dari kepuasan pengguna (satisfaction) dan $44 \%$ dari nilai layanan (service value). Dalam hal loyalitas penumpang, semua variabel mampu menjelaskan $75 \%$ dari perbedaan yang dijelaskan. Hasil penelitian menunjukkan bahwa kualitas layanan secara langsung dan positif mempengaruhi kepuasan pengguna dan nilai layanan. Selain itu, nilai layanan dan kepuasan merupakan faktor yang berpengaruh signifikan untuk perilaku loyalitas pengguna MRT-SBK. Sesuai dengan penelitian dari (Andreassen \& Lindestad. 1998; Butcher. 2001; Das et al. 2013) yang telah menemukan bahwa kualitas layanan memiliki korelasi positip dan keterkaitan yang signifikan dengan kepuasan pengguna.

Kualitas layanan memiliki efek positif dan tidak langsung terhadap loyalitas penumpang terhadap layanan publik tranport MRT-SBK melalui kepuasan pengguna dan nilai layanan, sesuai dengan penelitian (Lierop \& Geneidy, 2016). Hasil ini membuktikan bahwa kualitas layanan merupakan faktor utama atau vital yang dapat mempengaruhi kepuasan pengguna dan nilai layanan serta loyalitas mereka terhadap service mass rapid transit 
MRT-SBK. Dengan kata lain, jika kualitas layanan yang diberikan oleh otoritas MRT dengan baik, pengguna cenderung loyal atau setia terhadap layanan publik tranport ini.

Ini sejalan dengan (Parasuraman at al. 1885) yang menyebutkan jika pelanggan menerima kualitas layanan tinggi, mereka lebih berniat menggunakan atau membeli kembali merek / layanan tersebut. Menurut (Zeithaml. 1988) dan (Hellier at al. 2003), kualitas layanan dapat mempengaruhi loyalitas pengguna secara tidak langsung melalui nilai layanan. Selanjutnya, (Butche. 2001; Hellier. 2003; Irtema at al. 2018; Ostrowski. 1993) telah menunjukkan bahwa kualitas layanan memiliki pengaruh langsung pada kepuasan pengguna dan efek tidak langsung terhadap loyalitas penumpang melalui kepuasan pengguna.

Sebagai kesimpulan, studi ini menemukan penyedia MRT-SBK mampu menarik penumpang untuk terus menggunakan layanan mereka dengan meningkatkan kualitas layanan mereka seperti meningkatkan frekuensi kereta, meningkatkan waktu keberangkatan dan kedatangan kereta, meningkatkan kebersihan stasiun dan di kereta, dll. Kualitas layanan yang sangat baik akan memberikan nilai layanan yang lebih tinggi dan meningkatkan kepuasan penumpang terhadap layanan dan akhirnya dapat mempengaruhi penumpang untuk mengulangi penggunaan layanan dn mempromosikan kepada yang lain di masa depan. Studi ini membantu penyedia layanan MRT-SBK untuk mengoptimalkan sumber daya untuk meningkatkan kepuasan pengguna dan nilai perkhidmatan sehingga dapat meningkatkan loyalitas pengguna

\section{DAFTAR PUSTAKA}

A. Parasuraman, V. A. Zeithaml, and L. L. Berry, "A conceptual model of service quality and its implications for future research."Journal of Marketing, vol. 49, pp. 41-50. 1985.

Bernama,"10MP: RM2.8 billion for improving urban public transport," Bernama Oct 15, 2010, www.bernama.com.

Bernama, "600,000 targeting for public transport ridership in Klang Valley by End 2012," Bernama Dec 17, 2009, www.bernama.com.2009.

B. M. Byrne, "Modelling with AMOS: Basic concepts application and programming. Second Edition. New York: Routledge. 2010.

C. Flavian, E. Martinez, and Y. Polo, "Loyalty to grocery stores in the Spanish market of the 1900s," Journal of Retailing and Consumer Service, vol. 8, pp. 85-93. 2001.

C. Fornell, M. D. Johnson, E. W. Anderson, J. Cha, and B. E. Bryant, "The American customer satisfaction index: nature, purpose, and findings," Journal of Marketing, vol. 60, pp. 7-18. 1996.

Das, A. M., Ladin, A., Ismail, A., Rahmat, R. O. K. Consumers satisfaction of public transport monorail user in Kuala Lumpur Journal of Engineering Science and Technology (JESTEC) 8 (3): 272-283. 2013.

Essa, A. Ismail, A. E.Jehad, A. A. A. Hussein, and A. H. Khalaf, "Development of roundabout delay models using traffic simulation programs: A case study at Al-Mansour city," Jurnal Kejuruteraan, vol.9(2), pp. 97-107, 2017.

F. Hair, R.E. Anderson, R. L. Tatham, and W.C. Black, "Multivariate data analysis. prentice hall," Upper Saddle River, N.J. 1998.

H. A. M.Yahia, S. Safinia, N. K. A. Musharfi, S.I.A. Ali, "Car driver attitude towards road safety measures," Jurnal Kejuruteraan vol. 29(1), pp. 5761, 2017.

H. I. M. Irtema, H. I. M., Ismail, A., Borhan, M. N., Das, A. M., Alshetwi, A. B. Z. Case Study of The Behavioural Intentions of Public Transportation Passengers in Kuala Lumpur. Journal Case Study on Transport Policy, 6(4),462-474. 2018.

J. C. Anderson, and D. G. Gerbing, "Structural equation modeling in practice: a review and recommended two-step approach," Psychological Bulletin, vol. 103, pp. 411-423. 1988.

J. F. J. Hair, W. C. Black, B. J. Babin, and R. E. Anderson, "Structural equation modeling basics. Multivariate data analysis," vol. 1, pp. 1-35. 2009.

J. Mageean, and J. D. Nelson, "The evaluating of demand responsive transport service in Europa," Journal of Transport Geography, vol 11(4), pp. 255-270. 2003.

K. A. Bollen, "Structural equations with latent variables," John Wiley and Sons, New York. 1989.

K. Butcher, B. Sparks, and F. O'Callaghan, "Evaluative and relational influences on service loyalty," International Journal of Service Industry Management, Vol. 12, 310-327. 2001.

Ladin, M. A., Das, A. M., Najah, A., Ismail, A., Rahmat, R. O. K. Review of Strategies to Implement Sustainable Urban Transportation Options in Malaysia. Jurnal Teknologi (Sciences \& Engineering) UTM Malaysia 69:2, page 8590eISSN;2180-3722. 2014.

P. K. Hellier, G. M. Geursen, R. A. Carr, and J. A. Rickard, "Customer repurchase intention: a general structural equation model European Journal of Marketing. vol. 37, pp. 1762-1800. 2003.

P. L. Ostrowski, T. V. O’Brien, and G. L. Gordon, "Service quality and customer loyalty in the commercial airline industry," Journal of Travel Research, vol. 32, pp. 16-24. 1993.

SPAD (Land Public Transport Commission). Executive summary, "Greater Kuala Lumpur \& Klang public transport master plan”, 2010. 
T. W. Andreassen, and B. Lindestad, "Customer loyalty and complex services: the impact of corporate image on quality, customer satisfaction and loyalty for customers with varying degrees of service expertise," International Journal of Service Industry Management, vol. 9(1), pp. 7-23. 1998.

V. A. Zeithaml, "Consumer perceptions of price, quality, and value: a means-end model and synthesis of evidence," Journal of Marketing, vol. 52, pp. 222. 1988.

Van Lierop, D., El-Geneidy, A., 2016. Enjoying loyalty: The relationship between service quality, customer satisfaction, and behavioral intentions in public transit. Research in Transportation Economics, 59, 50-59.

W. B. Dodds, K. B. Monroe, and D. Grewal, "Effects of price, brand, and store information on buyers' product evaluations," Journal of Marketing Research, vol. 28, pp. 307-319. 1991. 